\title{
Pandora y Eva: la misoginia judeo-cristiana y griega en la literatura medieval catalana y española
}

\author{
MonTSERRAT Escartín GuAL
}

(UdG)

La tradición literaria occidental ha heredado un modelo de mujer atractiva, irresistible y de carácter mágico-demoníaco, cuyo poder se ha representado a través de la imagen de una serpiente. Ella, como otros emblemas bíblicos, posee una significación ambigua tanto en el Cristianismo, como en el Judaísmo o el Islam, ya que las tres religiones comparten el legado del Antiguo Testamento [Campbell 1992: 33]. La España medieval, nacida de la síntesis de todas, ellas la heredará, reforzándola con la aportación de la herencia greco-latina.

Muchos mitos hebreos proceden de culturas del Próximo Oriente, cuya iconografía relaciona la maldad con una mujer y este reptil. Dentro de la tradición mesopotámica, la Epopeya de Gilgamesh (2100-1800 a JC) explica que una ramera fue enviada a Enkidu para apartarle con sus artes sexuales del entorno natural en que vivía. Muerto dicho héroe, su amigo Gilgamesh fue en busca del secreto de la inmortalidad, oculto en una planta que acabó en poder de una serpiente. Imágenes similares aparecen en el Génesis cuando Adán es tentado por Eva para comer de la manzana y ella, por la serpiente, que simboliza el conocimiento. El papel seductor está repartido en dos figuras -Eva y el diablo en figura de serpiente-, siendo la mujer el verdadero portavoz del mal frente al hombre, que aparece como víctima de su persuasión. [Frenzel 1980: 337]

En la leyenda del paraíso sumerio, como en otros mitos de culturas vecinas, el reptil es emblema de la diosa y el árbol o planta sagrada, epifanía de la misma y símbolo de la fertilidad. Lo interesante en el relato del paraíso hebreo es la presencia de símbolos de otras mitologías reinterpretados con distinto significado. Así, la imagen de una serpiente divina, un árbol sagrado y una diosa enfurecida con su consorte (por haberse comido la planta mágica del paraíso sumerio), se convierten en la leyenda hebrea en un árbol cuya fruta es intocable, una seductora serpiente y un hombre que da vida a una mujer que acabará perdiéndole. Los roles se han cambiado y también el proceso de nacimiento que sitúa a la mujer en un plano secundario y negativo. De este modo, la antigua divinidad de los mitos orientales, dadora de 
vida, ${ }^{1}$ degeneró en simple mortal —Eva—, criatura formada de una costilla y responsable de una gran culpa. [Robbins 1990: 48]

Lo importante de esta comparación no es tanto identificar el origen sumerio de la iconografía tradicional asociada a Eva; sino comprobar que, muchos siglos después, la literatura medieval hispánica recordará este motivo para justificar la misoginia del momento. Dice Jaume Roig en su Llibre de les dones:

Déu, amb la seva mà, li tragué una costella i en féu la dona. Així manifestà el Creador la seva voluntat: li plagué que fos costella i no os recte; per això l'home i la dona mai no s'avenen, perquè un os recte i una costella mai no es poden ajustar (abans es trencaria que redreçar-se). Per això la dona no serà mai dòcil ni flexible com l'art turc. Després, va pendre la cueta d'una cabreta i li va fer la llengua: certament, bé va preveure Déu que seria xerraire. I amb mestria imposà nom a l'home i li digué Adam, que vol dir roig o vermell, i a la dona Eva, que segons la terra significa enuig, maledicció, perdició, rencor d'ossos o plor.

Después de su caída, no quiso confesar su error, sino que:

va intentar d'excusar-se atribuint la falta a la serpent, Déu la maleí, la bandejà del paradís i la comdemnà a parir amb dolor. Des de llavors, totes les seves successores han estat per sempre més, incapaces d'obeir, de servir, de reverenciar el marit i de ser bondadoses. [Cabré 1992: 84-85] ${ }^{2}$

Para la tradición hebrea, el aspecto más negativo de lo femenino se encarnó en la figura de Lilith. Su reputación procede de una vieja leyenda que la describe como la primera esposa de Adán. Al parecer, le exigió igualdad en la posición del acto sexual; razón por la que sobrevivió en la tradición esotérica de la Edad Media como criatura demoníaca poseída de una insaciable lujuria. Otros relatos del Antiguo Testamento - como los de José y la esposa de Putifar, Sansón y Dalila, etc.- - ayudaron a cimentar la misoginia en la literatura patrística al insistir en la idea de la mujer como ser puramente erótico y, en consecuencia, pecaminoso.

1 Una de las ayudantes de la diosa —encargada de sanar la costilla del héroe- se llama Nin- $t i$ 'la señora de la costilla'. En sumerio, uno de los significados de $t i$ es 'dar vida', como en hebreo Eva significa 'la que da la vida'.

2 «Dios, con su mano, le sacó una costilla y creó a la mujer. Así manifestó el Creador su voluntad: le gustó que fuera costilla y no hueso recto; por eso el hombre y la mujer nunca se entienden, porque un hueso recto y una costilla nunca se pueden ajustar (antes se rompería que enderezarse). Por ello la mujer no será nunca dócil ni flexible como el arco turco. Después tomó la cola de una cabrita y le hizo la lengua; ciertamente, bien predijo Dios que sería charlatana. Y con maestría impuso nombre al varón y le llamó Adán, que significa rojo, y a la mujer Eva, que según el lugar significa enfado, maldición, perdición, rencor de huesos o llanto» Después de su caída, como no quiso confesar su error, sino que «intentó disculparse atribuyendo la falta a la serpiente, Dios la maldijo, la expulsó del paraíso y la condenó a parir con dolor. Desde entonces, todas sus sucesoras han sido por siempre más, incapaces de obedecer, de servir, de reverenciar al marido y de ser bondadosas.» 
De los dos relatos del Génesis que describen la creación del hombre, la tradición cristiana divulgó más aquel que presentaba a Eva nacida de Adán, frente al de la creación simultánea de ambos. Se justificaba así la superioridad masculina por su mayor proximidad con lo divino, ya que el hombre fue creado a imagen (imago) de Dios y Eva sólo a semejanza (similitudo), por surgir del varón. Desde ese hecho quedó establecida la natural inferioridad de la mujer $a b$ origi$n e$, lo cual da por sentado Eiximenis cuando en el año 1388 afirma: «Dona és per natura menor que hom mascle». La caída sólo la intensifica, porque -insiste«Si Adam ne Eve no agessen pecat, ancara la dona fóra menor que l'hom.» ${ }^{3}$ [Alemany 1989: 75 y 76] En suma, el pecado original fue, para el hombre del siglo XIII, la cuestión más importante por justificar la presencia del mal en la Tierra; en consecuencia, no puede sorprender que Gonzalo de Berceo lo versificase en más de quince ocasiones. [Ruiz Domínguez 1989: 47]

Pero antes que la visión cristiana medieval reflejara tal animadversión hacia lo femenino, hay que detenerse en la cultura clásica para entender otra fuente que alimentó dicha actitud, ya que la mente griega también atribuyó a la mujer la causa de todos los males que dominaban la existencia humana y lo justificó mediante el mito de Pandora. En su Teogonía, Hesíodo la presenta como madre de las mujeres — no de toda la Humanidad-, especie que describe cual «raza maldita», terrible plaga instalada en medio de los hombres mortales. A su vez, en Trabajos y días, muestra cómo Pandora es enviada a modo de trampa y castigo, ${ }^{4}$ a la vez que instrumento de la venganza de Zeus contra Prometeo, a quien no logra engañar, pero sí a su hermano Epimeteo, cuya debilidad originará la pérdida del paraíso para la Humanidad, como en el Génesis: «A ellos (los hombres) yo, a cambio del fuego, les daré un mal con el que todos se gocen en su ánimo, encariñándose en su propia desgracia.» [Hesíodo 1990: 125]

Igual que Eva, Pandora es una mujer «hecha» y no engendrada. Como vimos en el Génesis, la genealogía mítica hace que los dioses engendren varones — es decir, parte de lo semejante a lo semejante-; pero la mujer no sigue la secuencia de la genealogía. Pandora es «fabricada por los dioses» y pertenece al plano de la «técnica», de lo «artificial», situada en lo más bajo del orden ontológico - en la línea del no-ser-, considerada un simulacro, un seductor engaño o señuelo que los dioses tenderán al hombre. El propósito de Hesíodo no es otro que remontarse a las causas, viendo la maldad como un castigo merecido. Si en la Teogonía Pandora es el mal mismo personificado, en Trabajos y días, es la causa de la difusión de las desdichas al abrir la jarra que lleva consigo. Con su acción, el espíritu del engaño y el hurto llega a la Humanidad, no en vano es la consecuencia de una transgresión (el robo prometeico). Pandora, formada de arcilla, está modelada y es exteriormente parecida a una diosa por su belleza; pero carece de inteligencia y bondad. Ella representa los límites de la

\footnotetext{
3 «la mujer es por naturaleza inferior al varón [...] Incluso si ni Adán ni Eva hubiesen pecado, todavía la mujer sería inferior al hombre».

4 «Vet aquí, doncs, Pandora, lluminosa a la manera d'Afrodita, i semblant a un fill de Nix, feta de mentides i coqueteria. Zeus crea aquest parthénos no per als déus, sinó exclusivament per als mortals.» [Vernant 2000: 71]
} 
condición humana, entre los dioses y los animales. Es un ser doble cuya apariencia divina no impide que en su interior esconda un corazón de perro. ${ }^{5}$ Este «bello mal» plantea al hombre su gran dilema: casarse para tener un beneficio - los hijos - y aceptar un mal - la propia mujer - , o no hacerlo y carecer del bien de la descendencia. En la mujer, por lo tanto, el bien y el mal se asocian como dos caras de una misma realidad. ${ }^{6}$

Debido a ello, la mítica figura de Pandora se asoció también con la muerte por ser responsable de la existencia de desgracias y enfermedades. En una tapicería medieval que representa El Triunfo de La Muerte sobre la Castidad (de una serie de seis imaginada por Petrarca), ${ }^{7}$ se ve a la tradicional figura de la Parca substituida por tres Hados precedidos por Pandora, quien - junto a «enfermedades y plagas»- está concebida como un heraldo precursor de la Muerte. ${ }^{8}$ Con la mano izquierda levanta la tapa de una vasija que lleva en la otra, permitiendo que escapen un montón de culebras y reptiles. ${ }^{9}$

Tras los pasos de Pandora desfilan por la literatura griega un buen número de herederas de su maldad: desde la fascinadora Helena, capaz de seducir a amigos, enemigos, e incluso a su marido y provocar el desastre de la guerra de Troya; a figuras como Circe, las Harpías o las Sirenas, que forjaron para siempre la imagen de la astucia femenina capaz de perder al hombre mediante sus atractivos eróticos. Ya sabemos, como nos dicen Jaeger [1967] y Marrou [1971], que los comentarios de Homero fueron para el mundo griego la fuente de toda su cultura, de la paideia del hombre educado que asimiló este legado misógino de sus cánones literarios. En sus mitos aparecen también demonios femeninos y monstruos (la Medusa Gorgona), seres intermedios entre la divinidad y el hombre (las llamadas Empusas o Lamias), cuyas fuerzas sobrenaturales originaron leyendas sobre la capacidad destructiva, hipnótica y vampiresca de la mujer.

El paralelo con el mito hebraico es obvio: si Pandora destapa la maléfica jarra, Eva come de la fatídica manzana, a la vez que las dos instauran la relación

5 «Aquest ésser femení, doncs, és modelat com una parthénos a imatge de les deesses immortals [...] Però Hermes també li posa paraules mentideres a la boca i la dota d'un esperit de gossa i un temperament de lladre.» [Vernant 2000: 70]. Las jóvenes atenienses se sometían a un rito frente a la diosa Artemisa para simbolizar el alejamiento de su naturaleza salvaje, domesticándola, para poder cohabitar con un hombre. [Vernant y Vidal-Naquet 1989: 39-40]

6 Hesíodo cree en un sino adverso para la Humanidad y es el primero en exponer la tesis de las Edades que van empeorando desde la inicial — de Oro - a la última — de Hierro-, en la cual los humanos han perdido sus virtudes a consecuencia de su maldad y, sobre todo, de la femenina. [Hesíodo 1990 : 103-134]

7 Las seis tapicerías medievales que representan los Triunfos de Petrarca se guardan en el Kunsthistorisches Museum de Viena.

8 En la Nueva Inglaterra del siglo XVIII, el término «Caja de Pandora» se aplicó a un receptáculo con instrumentos médicos diversos, análogo quizá al proverbial «maletín negro» del médico rural. En 1721 se preparaban «inoculadores» para estar «perfectamente abastecidos de lanceta de incisión, caja de Pandora, cáscara de nuez y filete» [Craigie y Hulbert 1942: 1676], citado por Panofsky [1975: 161].

9 «De ellos, una serpiente y un reptil cuadrúpedo ya han llegado al suelo.» [Panofsky 1975: 169] 
sexual, el matrimonio y un nuevo modo de reproducción que lleva implícita la generación y la muerte. En ambas tradiciones, la mujer es creada artificialmente con posterioridad al varón y, en las dos, es la culpable de introducir los males en el mundo por curiosa coincidencia que fijará el tópico de la flaqueza y la credulidad como defectos consustanciales a la naturaleza femenina.

Esta primera debilidad marcará toda la misoginia del medioevo occidental, ${ }^{10}$ que había asimilado a Aristóteles y aceptaba que la hembra era la materia pasiva a la que el varón daba entidad espiritual, o forma activa; es decir, la mujer era puro deseo sexual ante la mente equilibrada del hombre. Lo varonil era lo pensable; la mujer, un varón incompleto que no tenía lugar conceptual. Al tomar a Pandora como madre de la raza maldita de las mujeres, estas fueron pensadas genéricamente como «glotonas, lascivas, charlatanas», mientras que los varones tenían virtudes a título individual (Aquiles, Héctor...). Parafraseando al Estagirita, Santo Tomás insistió en la malignidad innata de la mujer y condición inferior en todos los aspectos: ${ }^{11}$ no era más que un hombre desviado, defectuoso y accidental, que debía someterse al varón por la debilidad de su naturaleza, tanto mental como física. Si Pandora es la madre del género femenino, Eva lo es de la Humanidad; y ambas, madres malditas de las que nace lo peor; frente a María, que será Madre Bendita del Salvador y de la Iglesia. En los siglos XII y XIII, se representa no sólo como modelo de conducta cristiana, sino también del orden social previsto para las mujeres, en su actitud obediente, humilde, resignada, y casta.

Junto al aristotelismo que invade el mundo medieval español, también llegan actitudes misóginas parecidas a través de algunos mitos presentes en obras literarias. Entre ellos, el de Pandora se consolida en nuestra literatura apoyándose en otros símbolos. Dado que el cuervo había tenido un significado negativo a lo largo del medioevo como ave de malos auspicios - la veíamos en el destierro del Cid: «A la exida de Bivar ovieron la corneja diestra, / e entrando a Burgos oviéronla siniestra» (vv. 11-12) [Riquer 1987: 80]—, no fue difícil sumar el sentido de ambas imágenes: la del cuervo, asociada al mal, ${ }^{12}$ y la de Pandora, identificada con el cuervo; luego mujer y mal, sinónimos. En los Emblemata de Alciato, 1534, texto muy difundido en la España del siglo XVI, el cuervo ya aparece como atributo de Pandora y símbolo de la Esperanza.

${ }_{10}$ Dice San Pablo: «la cabeza de todo varón es Cristo, y la cabeza de la mujer, el varón» [Corintios 11:3] «porque el marido es cabeza de la mujer, como Cristo es cabeza de la Iglesia... Así como la Iglesia está sujeta a Cristo, así también las mujeres deben estarlo a sus maridos en todo» [Efesios 5: 23-24]

11 Dice en la Summa Theologica: «La mujer está sujeta al hombre a causa de la debilidad de su naturaleza, tanto por lo que se refiere a la mente como al cuerpo [...] El hombre es el principio y fin de la mujer, como Dios es el principio y fin de cualquier criatura». En el siglo Xv, es de subrayar la reacción de Cristine de Pizan en La Ciutat de les Dames, tratado de educación para las mujeres en el que pretende demostrar la superioridad moral de éstas, atacando la actitud masculina consistente en menospreciar, con actos de fuerza o insultos, la naturaleza femenina que desconocen.

12 «Ave considerada mensajera de desgracias (principalmente, la muerte), siendo la suya una visión de mal agüero. En Occidente ha simbolizado el Pecado, la Mentira y el Demonio. [Revilla 1990:108] 
Los Padres de la Iglesia influyeron más que los propios autores clásicos en la transmisión del mito de Hesíodo, por cuanto tenían un objetivo muy concreto: corroborar la doctrina del pecado original mediante un paralelo clásico - Eva identificada con Pandora - aunque distinguiendo el valor de la narración cristiana (verdadera) sobre la fábula pagana (falsa). ${ }^{13}$ Un autor como Orígenes ${ }^{14}$ compara la historia del «jarro» ${ }^{15}$ griego con la de la fruta prohibida y ve el paralelo de ambas narraciones mitológicas al elegir el mismo símbolo para la idea del mal: la figura de una serpiente ${ }^{16}$ y una mujer llevada por su debilidad. La de Pandora al abrir el recipiente es semejante a la de Psyque; y la de Eva al tomar la manzana, ${ }^{17}$ parecida a la de Afrodita o Atalanta, nacida de la falsa etimología que hizo identificar la fruta tentadora de Eva con una manzana - asociando malum 'manzana' a malus 'mal'-, aunque en el Génesis nunca se menciona cuál es el fruto probado.

Así las cosas, la literatura de la época reflejó la relación entre Eva —culpable de introducir el pecado en el mundo-y la serpiente-demonio, símbolo de la tentación y el mal; lo cual fomentó, en los siglos XIII y XIV, una corriente misógina de opinión entre humanistas y miembros del estamento eclesiástico, como Jaume Roig, quien no duda en afirmar en su Llibre de les dones: «Has de saber que totes les dones són pecadores perquè així és la seva natura i així ho vol la seva voluntat.» [Cabré 1992: 84] ${ }^{18}$

${ }^{13}$ El paralelo entre Pandora y Eva fue una de los motivos favoritos de Milton. [Séchan 1929: 3 y ss.], Gottlieb [en Zobel 1723, cf.: 64] y [Estienne 1556: 5]

${ }^{14}$ Orígenes, Contra Celsum, IV (Patrologia Graeca, XI, cols. 1086 y ss).

${ }^{15}$ Erasmo de Rotterdam usa la palabra pyxis 'pequeño recipiente, la cual substituyó a la voz pithos o dolium 'vasija grande de almacenamiento', citada por Hesíodo; a partir de la cual se creó la popular expresión «caja de Pandora». Desde el siglo XV, la literatura recoge dicha idea y el arte la refleja. El responsable parece ser Erasmo de Rotterdam, en Adagiorum chiliades tres, I, CCXXXIII (ed. Princeps, Venecia, 1508 (aldus) fol. 35 v. Esta versión latina de la historia de Pandora estableció — sobre todas las clásicas — las versiones «modernas» cambiando la inicial «vasija de almacenamiento» por un vaso pequeño y transportable. Erasmo también atribuye a Epimeteo la acción de abrir la caja y no a Pandora.

${ }^{16}$ Existe una muestra iconográfica de un desnudo femenino en el Louvre, titulada «Eva Prima Pandora», pintada por Jean Cousin sobre el 1538, en el que una serpiente se envuelve alrededor del brazo derecho de Eva-Pandora. Un grabado de Giulio Bonasone, Miseria honorata ilustra un emblema humorístico de las Symbolicae Quaestiones, de Achille Bocchi, IV, 122, p. CCLIV, en el que aparece Pandora como símbolo del mal, reclinada en unas nubes a modo de ninfa acuática sobre su urna, de la cual surgen la destrucción y la muerte en forma de dos diablos y seis serpientes.

${ }^{17}$ La fruta es un motivo también presente en la mitología griega en más de una fábula. Eris la Discordia - suscitó la rivalidad entre tres diosas (Hera, Atenea y Afrodita), arrojándoles una manzana de oro con la inscripción: «para la más bella», a partir de lo cual se origina el famoso juicio para determinar cuál era más hermosa. Ganó Afrodita que había ofrecido al juez el matrimonio con la mujer más bella, Helena de Troya. En el caso de Atalanta, vemos a una joven virgen dotada para la carrera que se niega a casarse, salvo que algún pretendiente la gane en una competición. Melanión concurre a la prueba con las manzanas doradas que había recibido de Afrodita y, mientras es perseguido, las va arrojando. Así, por detenerse a recogerlas, Atalanta es vencida en la carrera y Melanión la toma por esposa.

18 («Has de saber que todas las mujeres son pecadoras porque así es su naturaleza y así lo quiere su voluntad.») 
Si en la naturaleza femenina va implícito el mal como rasgo distintivo de su sexo, no es extraño que en ella se viera algo monstruoso. De hecho Aristóteles definía al monstruo como «un pecado de naturaleza, con que por defecto, sobra, variación o diversidad, no adquiere el viviente la perfección que debía tener» [Fuentelapeña 1978: 167] De este modo, la mujer y el «monstruo» tenían en común ser deformes, representantes de las fuerza irracionales y estar cercanos a un cierto caos del que surgía la vida. La lengua fue sinécdoque del arma letal de ambos, por ello los dragones lanzaban fuego, las serpientes amenazaban con su lengua bífida y la mujer atemorizaba con su posible expresión verbal. En la $B i$ blia ya se advertía: «No hagas caso de la mujer perversa, / pues miel destilan los labios de la extraña, / su paladar es más suave que el aceite; / pero al fin es amarga como el ajenjo, / mordaz como espada de dos filos» [Proverbios 5, 2], temor que perdurará hasta Góngora [1981: 135], quien nos advierte:

amantes, no toquéis, si queréis vida;

porque entre un labio y otro colorado

Amor está, de su veneno armado,

cual entre flor y flor sierpe escondida.

Por ello, en el plano mítico-literario, el hombre acabará con esa amenaza cortando la cabeza al monstruo, como Perseo, quien exhibe la de Medusa a modo de trofeo.

En suma, para la mente griega, la mujer se emparenta con el mal y muchos monstruos en sus mitos (esfinges, sirenas, escilas, lamias...) expresan ese principio de maldad bajo la forma de un híbrido mujer-serpiente, ya que dicho animal es maléfico si encarna lo perverso. En consecuencia, cuando la patrística medieval recoge la tradición griega, continúa con la valoración negativa de lo femenino, haciendo de los monstruos con torso humano de la mitología clásica arquetipos de una sexualidad fuerte y primitiva que arrastra al varón. Ambas desmesuras - el peligro de la seducción corruptora ${ }^{19}$ y el conocimiento de los secretos más ocultos al hombre- son tenidas por peligrosas y se reflejan en las brujas y otras figuras legendarias de la tradición cristiana. ${ }^{20}$

${ }^{19}$ La misma Afrodita, la diosa de la belleza y del amor, lleva un cinto en el que advierte: «el lenguaje seductor que a los hombres más sabios hacer perder el juicio» [Ilíada XIV, 216-217]

20 Algunos rabinos sostienen que Sammael, príncipe de los diablos caídos, fue el íncubo que, bajo el aspecto de serpiente, sedujo a Eva y cohabitó con ella antes que Adán. De este concubinato nacieron otros demonios que encarnaron ambas naturalezas: la humana y la demoníaca. Por el contrario, hay talmudistas que afirman que fue Lilith, el diablo hembra o súcubo, quien cohabitó con Adán antes de que éste conociera carnalmente a Eva, de cuya unión nacieron también criaturas demoníacas. [Hervas 1974: 49] Las Lamias griegas son unas ogresas de naturaleza similar a la suya, ávidas de carne humana y libidinosas, con pies de caballo o cola de serpiente, que representan el poder de seducción y la crueldad. Son muy veloces y atrapan a los hombres seduciéndoles con su belleza para atacarles después con su parte serpentina, como hacía Lilith y sus compañeras en el Génesis. Las Lamias, o Empusae (forzadoras), se colocaban encima de los hombres durante el coito, a diferencia de Lilith quien, por no poder hacerlo, abandonó a Adán yendo hacia el mar Rojo donde permaneció junto a demonios lascivos. 
En la Edad Media múltiples leyendas, como la de Melusina, consolidaron la superstición del poder monstruoso en lo femenino, expresable bajo la forma serpentina. Su difusión a partir del relato de Jean d'Arras en el siglo XII quedó asegurada y, con él, la fábula de una esposa cuyo marido tenía que abstenerse de verla los sábados porque ese día se transformaba en un reptil al tomar su baño. Incumplido el mandato, y contemplada la metamorfosis, Melusina escapa a su mundo fantástico convertida para siempre en un híbrido de torso humano y cola de cinco metros. De este modo, la leyenda nos explica que lo impuro se halla en la propia naturaleza de la hembra, visible en su menstruación, como la serpiente fabrica su ponzoña. Ello implica que, periódicamente, la mujer se convierta en monstruo. Todavía a principios del XVI, Ambrosio Paré afirmaba en su tratado de Monstruos y prodigios: «Las mujeres manchadas por la sangre menstrual engendrarán monstruos.» [Paré 1993, III: 6-7]

Algunos tratados de medicina aseguraban que «la mujer estaba dominada por un animal interno - el útero, o animal avidus generandi - que buscaba el coito, producía la histeria (del gr. hysterá 'matriz)'y sometía a la mujer a ataques de «la madre», enfermedad peligrosa en la cual el furor uterinus provocaba trasponimientos y acentuaba la irracionalidad femenina» [MacKay 1989: 490]. Este fenómeno puede verse en La Celestina cuando la alcahueta recomienda mantener relaciones sexuales a una de sus pupilas aquejada de este mal.

Para Dante, este híbrido de cuerpo de reptil y cabeza humana fue el símbolo de Satanás, ya que la serpiente era invocada con frecuencia por su poder ctónico. ${ }^{21}$ Por ello, en las visiones medievales, los infiernos suelen representarse como un enorme monstruo marino ${ }^{22}$ emparentado con el dragón, animal que pertenece al grupo de las serpientes aunque las sobrepase en tamaño. Ser deglutido por él equivaldría a morir, a penetrar en el infierno. Esta explicación era innecesaria en el medioevo, ya que ningún cristiano de entonces necesitaba acudir a textos determinados para entender la iconografía de los pecados en figura de sierpes. En la literatura española aparecen en el infierno del Libro de Aleixandre, concebido en el siglo XIII, ${ }^{23}$ y en El Dezir de las siete virtudes de Francisco Imperial, quien encuadra y actualiza en el siglo XV la vieja oposición de vírgenes y monstruos usando el simbolismo de siete doncellas y siete serpientes, sumando la herencia clásica de Prudencio y su Psychomachia a la alegoría cristiana de Dante. [Lapesa 1971: 84]

En definitiva, para la Edad Media, «El Diablo, la Mujer, el Monstruo, se encuentran, y van a constituir, por parejas o en conjunto, una poderosa unidad»

${ }^{21}$ La estatua de una Diosa en el templo cretense de Knossos con una serpiente en cada mano lo muestra.

${ }^{22}$ Caso del Leviatán bíblico o Tifón para el mundo griego, en cuya mitología muchos de los monstruos femeninos proceden de una divinidad marina. Es el caso de Forcis, personaje de la primera generación de dioses, padre de las Grayas, las Fórcides, de Escila, Equidna, abuelo de las Furias... [Vid. Asín Palacios 1961]

${ }^{23}$ «Sylvan por las riberas muchas malas sirpientes, / están días e noches aguzando los dientes, / asechan a las almas, non tienen a ál mientes; / por eso peligraron los primeros parientes.» [Lapesa 1971: 84] 
[Kappler 1986: 274], ya que enfrentarse a la mujer, y al misterio que encierra, es bajar a los infiernos; ${ }^{24}$ no en vano, según San Jerónimo: «la mujer era la puerta del demonio, la patrona de la perversidad, la mordedura de la serpiente» ${ }^{25}$ es decir, la muerte. También monstruo y mujer lasciva se unen en las representaciones del Apocalipsis de San Juan, donde una prostituta cabalga la Bestia Bermeja. La «Ramera del Apocalipsis» se identifica con la serpiente porque este animal, como otros con ella emparentados, es para la mitología cristiana símbolo de la sexualidad y una misión maléfica.

No sorprende, pues, que el arte y la literatura medievales identificaran la culpabilidad de $\mathrm{Eva}^{26}$ con la imagen de este reptil y del demonio, símbolo de la tentación, la lujuria y el adulterio. De hecho, los diablos con pechos aparecen a fines del siglo XV, cuando lo femenino era ya símbolo de malditismo. La lujuria se representaba mediante una mujer con serpientes, a modo de demonio, para reflejar visualmente la lascivia (así puede verse en el pórtico de la iglesia de Moissac en Francia y en La Celestina, donde Melibea se siente «llena de serpientes» cuando la domina el deseo por Calixto). Pero la iconografía que representa a Satanás como hembra no se reduce a libros de horas medievales, sino que es visible en obras maestras de la cultura occidental que consolidaron el prejuicio a lo largo de centurias. En el techo de la Capilla Sixtina, Eva toma la manzana de una seductora y musculosa mujer-serpiente, cuya visión nos recuerda lo dicho por San Ignacio de Loyola: «El enemigo se comporta como una mujer. Es débil ante una muestra de fortaleza, y un tirano si logra su voluntad».27

En resumen, en el infierno imaginado por la mente medieval, además de la presencia del fuego, el castigo principal que en él se da es el ataque de serpien-

${ }^{24}$ El descenso a los infiernos en los misterios de Eleusis es un ritual de iniciación femenino que suponía una muerte para hallar una regeneración espiritual. Los «mortales» descubrían que ellos eran «dioses» y no esclavos de un poder religioso. Mientras que las iniciaciones masculinas consistían en un «nacimiento» al mundo de la ley como adulto responsable, en un acceso al poder; las femeninas se experimentaban como una muerte en que la mujer se liberaba de imposiciones y leyes, al diluirse en la naturaleza, para regenerarse espiritualmente.

${ }^{25}$ La relación entre ambas procede de las antiguas sociedades ginecocráticas, que siempre vincularon el poder femenino con el misterio de la religión ctónica. La diosa egipcia Isis obtuvo su poder por astucia al crear una serpiente que mordió a Ra. Isis advirtió al dios sol que sólo se curaría si pronunciaba su nombre secreto (es decir el conocimiento divino). Cada vez más enfermo por el veneno, Ra se vio obligado a hablar, e Isis pudo apoderarse, con el nombre del dios, de una parte de su poder. [Comte 1992: 125]

${ }^{26}$ Se escriben tratados contra el loco amor, como El Corbacho del Arcipreste de Talavera (en el que se afirma que la mujer es la causa de la destrucción moral del hombre, por ser la personificación de los siete pecados capitales), y poesías que ridiculizan y atacan a la mujer: «De natura de lobas son / ciertamente en escoger, / de anguilas en retener [...] Son todas naturalmente / malignas y sospechosas, / mal secretas, mentirosas, [...] Mujer es un animal / que se dice imperfecto, / procreado en el defecto / de buen calor natural», Pedro Torrellas, «Coplas de maldecir de mujeres» [Cancionero General 1971: 180-184]

27 San Ignacio, regla 12 [1963: 265]. No es difícil entender que muchas mujeres, entre los siglos XI-XV, participasen en los movimientos heréticos y heterodoxos (como el catarismo) que ofrecía una igualdad de valoración ante el hombre que el catolicismo les negaba. 
tes. En el Beato de Gerona, se puede ver a dicho reptil mordiendo el pecho de los condenados o sobre el del Gran Diablo. ${ }^{28}$ Parece que la imagen de este animal como atormentador de pecadores está tomada de las descripciones orales del Infierno musulmán conocidas por los cristianos, las mismas que debieron servir de modelo a Dante para sus visiones infernales («Los ricos y soberbios son atormentados por serpientes y alacranes», otros «son agarrados por los demonios, mientras las serpientes penetraban por sus bocas, rompían sus intestinos y salían por sus anos», «Los usureros tienen el vientre hinchado y lleno de serpientes y alacranes», etc.). ${ }^{29} \mathrm{El}$ románico también representó el castigo de la lujuria cambiando el signo de fecundidad de un niño unido al pecho de una mujer por el de una serpiente atacándola. ${ }^{30}$

Sea la griega o la hebraica, lo difícil para una cultura patriarcal es aceptar que la mujer sea el canal a través del cual se transmita el conocimiento divino. ${ }^{31}$ A pesar de esa reticencia, la mitología nos muestra a la mujer como guardiana de grandes misterios: sea Afrodita, del mundo telúrico de las pasiones; Circe, de la magia amorosa o hechizos cautivadores; Casandra, del porvenir..., ${ }^{32}$ frente a un Zeus, cuyo poder máximo le llega tras ingerir a su esposa Metis, diosa de la astucia; o Apolo, cuyo don oracular procede de Pitón, la serpiente adivina a quien dio muerte. De hecho, Porfirio ya había sugerido que Pandora no era sólo la pura representación del placer, el riesgo de la seducción corruptora ${ }^{33}$ sino también la poseedora del conocimiento de los secretos más ocultos al hombre. Los dos aspectos eran tenidos por peligrosos y se representaron con el ambiguo simbolismo de la serpiente: pecaminosa por su aspecto reptil y positiva por su don de ser inmortal o salutífera.

${ }^{28}$ Se observa un extraño ser de largo cuerpo — con serpientes y alacranes—, dos patas acabadas en garras y varias cabezas mordiendo las de los condenados. Beato de Gerona (976), fol. $17 \mathrm{v}$. Descensus ad inferos, catedral de Gerona.

${ }^{29}$ [Asín Palacios 1961] defiende que Dante se inspiró en textos escatológicos musulmanes para describir el Paraíso y el Infierno.

${ }^{30}$ Porque, en general, para el arte de los siglos XI y XII, lo normal es que la lujuria se representase mediante algún personaje femenino danzando convulsivamente y recibiendo el castigo infernal a través de las serpientes que le comían sus pechos y sapos que devoraban su sexo. «La que mostraba su desnudez había de ser deshonesta. Si unos animales tan negativos como la serpiente se pegaban a sus pechos era porque el castigo a su impudicia se debía a quien estaba emparentado con el mismo diablo, que había adoptado su forma para tentar a Adán y Eva, y en el infierno pronto estaría entre las bestias que lastimaban a los hombres.» [Yarza 1987: 103-104 y 242]

${ }^{31}$ Sócrates se comparaba con una partera que ayudaba al hombre a nacer a la conciencia de sí mismo. Pero, la diferencia entre un sacerdote (traductor) y una sacerdotisa (transmisora) era la capacidad de ella para recibir y dar, lo cual la convertía en un canal perfecto para lo trascendente. [Vid. Dunn 1992: 206]

${ }^{32}$ En La leyenda del santo Graal, claramente iniciática, son mujeres quienes revelan al héroe los máximos enigmas: una doncella lleva el santo Graal, la prima de Perceval es la encargada de desvelarle al protagonista la simbología de su nombre, una mujer horrible le anuncia sus futuras desgracias, su madre le protege...

${ }^{33}$ La misma Afrodita, la diosa de la belleza y del amor, lleva un cinto en el que advierte: «el lenguaje seductor que a los hombres más sabios hacer perder el juicio» [Ilíada XIV, 216-217] 
En la tradición bíblica, también se le reconoce esa dualidad. Por un lado, tienta al hombre a comer del fruto del árbol prohibido y le pierde ${ }^{34}$ pero, a su vez, le da el conocimiento de las cosas..$^{35}$ En el Génesis, la maldición divina había recaído en la serpiente antes que sobre la mujer. ${ }^{36}$ Por otro lado, también es positiva (desde el momento en que Cristo se convierte en «la serpiente de salvación» trepando sobre la vieja serpiente del destino). En el mundo griego, su nombre ophis, está muy cerca de sophia 'sabiduría'. Esa relación con la inteligencia explica que muchos sacerdotes antiguos fueran encantadores de serpientes, como Pitón fue el reptil que presidió el oráculo de Delfos hasta que Apolo la mató; de ahí el nombre de pitonisa a la sacerdotisa encargada de atenderlo. En definitiva, la serpiente representa, como la mujer, la unión de dos corrientes de signo contrario: la seducción que arrastra al mal y la curiosidad e intuición, cualidades ambas imprescindibles para el conocimiento. Ese dualismo se reflejó en la ambivalencia de trato que los textos medievales le dispensaron: positivo en la figura inmaculada de la Virgen, que invertía el simbolismo de Eva al aplastar una serpiente, mostrando el aspecto celestial de lo femenino en obras marianas como los Milagros de Berceo o las Cantigas del rey Alfonso; y la mujer perversa, Eva revivida en formas serpentinas y depreciada en sátiras y cuentos. Boccaccio fue el iniciador de esta polémica respecto de las mujeres con su De claris et virtuosis mulieribus, en lo positivo, y su Corbaccio en lo negativo, que llenaron nuestra literatura del siglo XV de muestras de ambas concepciones. La Cárcel de amor de Diego de San Pedro, como defensa, o El Corbacho del Arcipreste de Talavera, como denuesto.

Pero es en los cuentos donde se produce la fusión de las actitudes misóginas vistas en la cultura griega y cristiana con otras, como la musulmana. El Calila e

${ }^{34}$ Dice en el Llibre de Fra Bernat, Francesc de la Via: «Eva va fer pecar Adam, fent-lo menjar el fruit, i, per això, vam ser condemnats tots a patir gran dolor; perquè les dones han dut la tristesa a la nostra natura.» [Cabré 1992: 122]

${ }^{35}$ La simbología de la Antigüedad tenía a este animal por guardián de la fuente de vida y, en consecuencia, de la inmortalidad; además de símbolo de la iniciación, por ser un intermediario con el mundo infernal. Se creía que algún dios había otorgado el don de rejuvenecerse a los humanos; aunque, por error, recayó sólo en serpientes y lagartos; es decir, en animales que mudaban de piel (Epopeya de Gilgamesh). De este modo, la sierpe aparece vinculada a aspectos divinos: sea enroscada en el caduceo de Hermes, en el omphalos délfico, en la copa de Esculapio, en la lanza de Atenea (madre adoptiva de Erictonio, niño con forma de serpiente), en la genealogía de Afrodita, la diosa del amor nacida de la unión de una serpiente con las aguas, etc. El vínculo serpiente-mujer nace del poder de ambas de apartar al hombre de la racionalidad para arrastrarle al terreno del corazón. La seducción no se produce si la mente actúa y la mujer puede provocar la detención del pensamiento en pro de la percepción sensual, cuyo poder es lo que hace ver algo demoníaco en ella (Salomé). Si la sierpe se consideró maléfica cuando defendía tesoros o árboles sagrados (símbolos del saber o la inmortalidad), no es raro que la mujer, poseedora de una sabiduría específica, se identificara con la maldad serpentina.

36 «Por haber hecho esto, / maldita seas entre todas las bestias / y entre todos los animales del campo. / Sobre tu vientre caminarás, y polvo comerás / todos los días de tu vida. / Enemistad pondré entre ti y la mujer, / y entre tu linaje y su linaje: él te pisará la cabeza / mientras acechas su calcañar.» [Génesis 3,14] Por ello, y en relación al peligro que representaba, se cambió su nombre latino por el de «serpens», «la que se arrastra», en un intento de no atraer la ira de este animal feroz. [Rodríguez Adrados 1993: 1] 
Dimna $^{37}$ y el Libro de los engaños e asayamientos de las mugeres son las primeras compilaciones en castellano de textos árabes traducidos a mediados del siglo XIII. Será precisamente en la época alfonsí, gracias a la escuela de traductores y a su labor intercultural, cuando se fundirán las diversas tradiciones estudiadas al desarrollarse colecciones de exempla y muestras de literatura sapiencial procedentes de filósofos clásicos u orientales. De la colección de cuentos árabes del Sendebar ${ }^{38}$ se desprende la idea que las mujeres son un mal que no hay que lamentar perder, pues son tantos sus engaños que no pueden escribirse, siendo abundantes los cuentos misóginos - la mayoría basados en el motivo del marido engañado por la mujer infiel o la adúltera frustrada-, rasgo este no sólo del Sendebar, sino de toda la literatura oriental que se traduce. Veamos algunas de sus moralejas:

$\mathrm{E}$, señor, non te di este enxemplo sinon que non creas a las mugeres que son malas, que dize el sabio que «aunque se tornase la tierra papel, e la mar tinta e los peçes della péndolas, que non podrían escrevir las maldades de las mugeres». E el rey mandola quemar en un caldera en seco. [Sendebar 1989: 154155] E yo, señor, non te di este enxemplo sinon por que sepas el engaño de las mugeres, que son muy fuertes sus artes e son muchos, que non an cabo ni fin, [...] non mates tu fijo por dicho de una mujer, ca las mugeres, ayuntadas en sí, an muchos engaños. [Sendebar 1989: 85 y 93]

Dichos prejuicios alimentaban los Libros de sentencias, como el titulado Bocados de oro o Libro de los buenos proverbios, en los que hay que buscar el apoyo teórico de la filosofía de estos apólogos. ${ }^{39}$

También la literatura hebrea medieval asocia la mujer con el sexo, el diablo o la maldad. Sirvan de ejemplo tres obras de fines del siglo XII y principios del XIII: La ofrenda de Yehudah, el que odia a las mujeres, del médico judío Yehudah ben Isaac ibn Sabbatay; El libro de los entretenimientos, del médico barcelonés Yosef ben Meir ben Zabarra; y El sabio, del escritor judío Al-Harizi. Las tres fueron escritas en la península ibérica, en hebreo, en fechas próximas a la época alfonsí y en prosa rimada de carácter lúdico (cercana al género árabe de la maqama), con la presencia de una alcahueta y debatiéndose en ellas la maldad de

37 «El carpintero engañado por su mujer», del Calila e Dimna, está en la línea de «Lo que sucedió con sus mujeres a un emperador y a Alvar Fañez Minaya» y «Lo que sucedió a un filósofo que por casualidad entró en una calle donde vivían malas mujeres», de El conde Lucanor.

${ }^{38}$ Nombre dado a la compilación de ocho textos conservados, del llamado Libro de los Engaños (primera traducción castellana de una obra de origen desconocido y procedencia oriental). Sendebar significa 'el sabio encargado de instruir a un príncipe'. En él se cuenta cómo el hijo del Rey es condenado a muerte por su padre tras la calumnia de una de sus mujeres. La ejecución se retrasa por la intervención alterna de varios consejeros y la mujer que, con sus narraciones, hacen cambiar la opinión del monarca.

${ }^{39}$ He aquí un ejemplo de cada uno: «E vido una mujer quemada que estaba colgada de un árbol e dixo: -Agora levassen todos los árboles tal fructo.» [Sturm 1971: 138] «E vido una mujer que llevaban a soterrar, e mugeres que lloravan enpos d'ella, e dixo: -Duele-se el mal porque pierde al mal.» Bocados de Oro [Crombach 1971: 63] (el subrayado es nuestro). 
la mujer. En todas, la moraleja es clara: «las mujeres son peores que demonios» [Forteza-Rey 1990: I]

Desde la mítica «jarra» de Pandora, lo femenino como receptáculo, como vasija, halló sólo su razón de ser en la procreación. En paralelo, el Cristianismo insistió en oponer a Eva - cáliz del pecado - la Virgen, vientre de salvación, o la Iglesia, dadora de vida con la copa sagrada (el simbólico Santo Grial de Chrétien de Troyes), obligando a la mujer a redimirse por el matrimonio y a expiar sus culpas por la maternidad. En dicho contexto, es meritorio que Alfonso X dedicase el capítulo central de sus Partidas - el IV de su setenario- a la regulación del contrato matrimonial, dándole un valor trascendente y dignificador. ${ }^{40}$ Aunque, centurias después, para luteranos y calvinistas, el matrimonio se transformase en el correctivo para controlar el deseo carnal de la mujer y la maternidad con dolor, el castigo divino y único medio de salvarla. ${ }^{41}$ Fueron pensadores como Calvino, Lutero y otros reformistas quienes siguieron atribuyendo a Eva la responsabilidad de la caída y difundiendo la heredada misoginia medieval. Un pastor luterano afirmaba en el siglo XVI: «Las mujeres aún son Eva, ellas aún sostienen la manzana en sus manos». ${ }^{42}$ Después de todo, como dijo Lutero: «Adán fue tentado no por la serpiente, sino por la mujer». Cuando el canon cristiano fue establecido por los padres de la Iglesia, la Biblia hebrea se incluyó en la revelación divina y el Génesis se convirtió en la historia de la creación para la cultura occidental. Así, el Cristianismo suprimió o pervirtió todos los símbolos del poder femenino como la serpiente-, que de ser emblema positivo del poder regenerador de una Diosa primordial pasó a ser imagen negativa de la lujuria y lo diabólico.

Todavía en los albores del siglo XX, la maldad o perversidad asociada a la mujer siguió utilizando como símbolos a princesas de la Antigüedad, famosas por su vileza (Salomé, Helena, Yanthis, Yeldis, Melisanda, Cleopatra, Salambó, Broncelianda, Armida...). Valle Inclán describe a la amada del Marqués de Bradomín comparándola con la Lilith del mito hebreo, la primera esposa de Adán: «Tenía la misma sonrisa de Lili. Aquella Lili, no sé si amada, si aborrecida» —explica - cuya figura «hierática y serpentina» revivía la del genio femenino del mal. ${ }^{43}$

La Edad Media española ayudó a la difusión del prejuicio de lo diabólico vinculado a lo femenino y sus símbolos porque la tradición judeo-cristiana le había suministrado demasiados ejemplos donde la mujer utilizaba su cuerpo como moneda de cambio para obtener algo. ${ }^{44}$ Según una leyenda egipcia, el saber al-

${ }^{40}$ El Título VI, por ejemplo, posee dos leyes sobre: «Cuál debe el rey seer a su muger et ella a él», «Cuáles cosas debe el rey catar en su casamiento», Ley I y «Cómo el rey debe amar, et honrar et guardar a su muger», Ley II.

${ }^{41}$ «Aunque se agoten y al final mueran de tanto parir, no importa que mueran de parto, para eso existen.» Lutero.

${ }_{42}$ Conrad Sam, el pastor luterano de Ulm, escribió en 1534 «Women are stil Eve, They still hold the apple in their hand.» [Dackerman 1993: v 3]

43 Valle Inclán, Sonata de estío, Madrid, Austral, 1991.

${ }^{44}$ Citaremos tres obras de la literatura judía del siglo I a. C-I d. C. La vida griega de Adán y Eva, los Testamentos de los Doce Patriarcas y el Testamento de Job; en los que la mujer aparece como seductora, perversa o encarnación de Satán. [Fernández Marcos 1993: 277] 
químico nació por la resistencia de la diosa Isis ante un ángel y el demorarse en ceder a su demanda sexual a cambio del conocimiento. En el Antiguo Testamento, se cuenta que las hijas de los hombres obtuvieron el arte de la forja y de la alquimia prostituyéndose con los ángeles guardianes o robándoselo. ${ }^{45}$ Mientras que el mito de Isis considera un gran logro la obtención del secreto en poder de los ángeles por parte de la diosa; en la tradición cristiana se valora negativamente el hecho que las mujeres se adueñaran de estos secretos, contribuyendo a la corrupción de nuestro mundo. Este mito subraya que todo el mal procede de las hembras, como la historia de Eva en el Génesis insiste en que nuestra madre intentó conseguir de Dios el conocimiento y lo obtuvo, además de la desgracia. El resultado, para la tradición Occidental, es el sentimiento de que el principio femenino obtiene el saber de estratos más profundos y es el mediador que se lo entrega a la Humanidad, aportándole un mal. Por ello, desde la Biblia, la curiosidad y flaqueza han sido los puntos vulnerables de la naturaleza femenina. Eva cedió a las palabras de la serpiente por querer alcanzar el conocimiento, como cederían después Loth y Sodoma. Con esta valoración del mito bíblico, nuestra tradición ha calificado de peligrosa la curiosidad de la mujer y ha transmitido su prejuicio misógino tanto a la literatura culta como al legado folklórico. ${ }^{46}$

Para el mundo griego, la valoración de la mujer se expresó de manera similar, ya que el cargo imputado a Pandora por abrir la urna de donde escaparon los males fue ser curiosa. Debilidad análoga a la que privó a Psique de su dicha, al querer contemplar el rostro de Cupido; aquella que en Parsifal arrebata el esposo a la princesa de Brabante por haberle preguntado quién era. Idéntica a la que hizo perder su carrera y su virginidad a Atalanta por detenerse a observar unas manzanas lanzadas a su paso; la que sumirá en un profundo sueño a Blancanieves tras gustar la fruta en el cuento de La Bella durmiente; la misma, en definitiva, que revive la herencia ancestral de una Eva culpable de perder a la Humanidad por su afán de saber.

\section{BIBLIOGRAFÍA}

Alciati, Emblemata, Ausburgo (Wechel), 1534.

Alemany Ferrer, R., «Aspectos religiosos y ético-morales de la vida femenina en el siglo XIV, a través de lo Llibre de les dones de Francesc Eiximenis», en [Muñoz Fernández 1989].

Asín Palacios, M., La escatología musulmana en la Divina Comedia, Madrid, 1961.

${ }^{45}$ A veces se habla de relaciones con gigantes en lugar de seres angélicos. Según el Testamento de Rubén, la maldad de las mujeres consiguió seducir con engaños a los Vigilantes como las sirenas lo hicieron con los hombres; por lo que el saber pasó de estos espíritus celestiales a las mujeres.

${ }^{46}$ La esposa de «Barba Azul» cae en el mismo error que sus predecesoras al penetrar en la estancia prohibida por su esposo. «Este cuarto secreto parece ser el lugar del saber por excelencia» y el color de la barba del marido hace pensar en el «iniciador, el conductor de las almas que hace franquear las puertas de la muerte espiritual», Ibídem. 121-120. También en Las mil y una noches se hace de la curiosidad una larga interpretación. 
CABAllé, Anna, Una breve historia de la misoginia, Barcelona, Lumen, 2000.

CABRÉ, Nuria, Dona i literatura la imatge de la dona en la literatura medieval, Barcelona, Laertes, 1992.

Campbell, Joseph, Las máscaras de Dios, Madrid, Alianza, 1992.

Cancionero General de Hernando del Castillo, Madrid, Anaya, 1971

CANET VAlLÉs, José Luis, «La mujer venenosa en la época Medieval», Lemir: Revista de Literatura Española Medieval y del Renacimiento, n. ${ }^{\circ}$ 1, 1996-1997.

Clowes, Daniel, Monstruos, fantasmas y más mujeres fatales, Barcelona, La Cúpula, 2007.

Crombach, Bonn, M. (ed.), Bocados de Oro, Romanistische Versuche und Vorarbeiten, 37, 1971.

Comte, F., Las grandes figuras mitológicas, Madrid, Ed. del Prado, 1992.

Craigie, W.A., y Hulbert, J.R. (eds)., A Dictionary of American English on Historical Principles, III, Chicago, 1942.

Dackerman, S., Chaste, Chased, \& Chastened, Old Testament Women in Nothern Prints, Harvard University Art Museum Gallery Series, n. ${ }^{\circ}$ 6, 1993.

Detienne, Marcel y VernAnt, Jean Pierre, Las artimañas de la inteligencia, La metis en la Grecia Antigua, Madrid, Taurus, 1988.

DuBy, Georges, El caballero, la mujer y el cura, Madrid, Taurus, 1988.

--, Mujeres del siglo XII. Santiago: Editorial Andrés Bello, 1998. Vol. III

DunN, M., Diosas, Barcelona, Robinbook, 1992.

ESTIENNE, Henri, L'introduction au Traité de la conformité des merveilles anciennes avec les modernes, París, 1556, p. 5 y ss.

FERnÁNDEZ MARCos, N., «Exégesis e ideología en el judaísmo del siglo I», en Sefarad, Madrid, 1993, LIII, n. ${ }^{\circ} 2$.

Ferrante, Joan M., Woman as Image in Medieval Literature, Columbia, University Press, 1975.

ForTEZA-REY, M.S., «El personaje de la intermediaria», Sefarad, Madrid, 1990, año L, fasc. I.

FREIXAS, Laura, «La marginación femenina en la cultura», El país, 3 de mayo 2008, p. 29.

FrEnZEL, Elisabeth, Diccionario de motivos de la literatura universal, Madrid, Gredos, 1980.

FuENTElAPEÑA, Fray Antonio de, El ente dilucidado: tratado de monstruos y fantasmas (ed. Javier Ruiz), Madrid, Editora Nacional, 1978,

GóngORA, Sonetos completos, Madrid, Castalia, 1981.

GotTlieb Schwarz, Christian, disertación presentada en Nuremberg por N.E. Zobel, Dissertatio inaguralis de lapsu primorum humani generis parentum a paganis adumbrato, Altorf (Franconia), 1723, cf., p. 64 y ss. 
Hervas Marco, Ramón, Los hombres-monstruo, Barcelona, Bruguera, 1974.

Hesíodo, Trabajos y Días, Madrid, Gredos, 1990.

HinterhäUSER, Hans, Fin de siglo. Figuras y mitos, Madrid, Taurus, 1998.

IGNACIO DE Loyola, Ejercicios espirituales, Obras Completas, Madrid, BAC, 1963.

IRIARTE, Ana, Las redes del enigma. Voces femeninas en el pensamiento griego, Madrid, Taurus, 1990.

JAËGER, Werner, Paideia. Los ideales de la cultura griega, Madrid, FCE, 1967.

KAPPLER, Claude, Monstruos, demonios y maravillas a fines de la Edad Media, Madrid, Akal, 1986.

LAPESA, Rafael, «Notas sobre Micer Francisco Imperial», De la Edad Media a nuestros días, Madrid, Gredos, 1971.

MacKaY, A., «Mujeres y religiosidad», en [Muñoz Fernández 1989].

MARrou, Henri-Irénée, Historia de la educación en la antigüedad, Madrid, Akal, 1986.

Michelet, Jules, Historia del satanismo y la brujería, Buenos Aires, Dédalo, 1989

MuÑoz FERnÁNDEZ, A. (ed), Las mujeres en el cristianismo medieval: imágenes teóricas y cauces de actuación religiosa, Madrid, Asociación cultural Al-Mudayna, 1989.

PARÉ, Ambroise, Monstruos y Prodigios, Madrid, Siruela, 1993.

PANOFSKY, Dora y Erwin, La caja de Pandora: aspectos cambiantes de un símbolo mítico, Barcelona, Barral, 1975.

PhILlIPS, John, Eva.La historia de una idea, México, FCE, 1988.

PIZAN, Christine de, La ciutat de les dames, Barcelona, ed. de L'Eixample, 1990.

POMEROY, Sarah B., Diosas, rameras, esposas y esclavas. Mujeres en la antigüedad clásica, Madrid, Akal, 1987.

Revilla, Federico, Diccionario de Iconografía, Madrid, Cátedra, 1990.

Robisns, M., Whence The Goddnesses, New York, Pergamon Press, 1990.

RiQuer, Martí de, Cantar de mío Cid, Madrid, Espasa-Calpe, 1987.

RodríGuez Adrados, Francisco, «Los nombres y las cosas», $A B C, 12$ de Abril de 1993, p. 1.

RoIG, Jaume, Llibre de les dones, Barcelona, Laertes, 1988.

Ruiz Domínguez, J.A., «Pecadoras y santas en el mundo de Gonzalo de Berceo», en [Muñoz Fernández 1989].

SÉCHAN, L., «Pandora, l'Eve grecque», Bulletin de l'Asssociation Guillaume Budé, XXIII, 1929, p. 3 y ss.

Sendebar, Madrid, Cátedra, 1989.

STURM, H. (ed.), Libro de los buenos proverbios, Lexington, The University Press of Kentucky, 1971. 
TORrellas, Pedro, «Coplas de maldecir de mujeres», en Cancionero General de Hernando del Castillo, Madrid, Anaya, 1971.

VAlle InClán, Sonata de estío, Madrid, Espasa-Calpe, 1991.

Vernant, Jean Pierre y Vidal-Naquet, Pierre, Mito y tragedia en la Grecia antigua, Madrid, Taurus, 1989.

VERnANT, Jean-Pierre, L'univers, els déus, els homes, Barcelona, Empúries, 2000.

YARZA, Joaquín, Formas artísticas de lo imaginario, Barcelona, Anthropos, 1987. 